\title{
Effects of Continuous Teacher Professional Development in Engineering on Elementary Teachers
}

\section{Dr. So Yoon Yoon, Texas A\&M University}

So Yoon Yoon, Ph.D., is a post-doctoral research associate at Texas A\&M University. She received her Ph.D. and M.S.Ed.in Educational Psychology with the specialties in Gifted Education and Research Methods \& Measurement, respectively, from Purdue University. Her work centers on the development and validation of instruments, particularly useful for P-16 STEM education settings (e.g., the Revised PSVT:R, the Teaching Engineering Self-efficacy Scale [TESS], the extended Student Attitudinal Success Inventory [e-SASI]), the evaluation of engineering teacher professional development programs, and the investigation of P-16 students' spatial ability to understand its association with their academic performance and talent development in STEM fields.

\section{Miss Yi Kong, Purdue University, West Lafayette}

Yi Kong is a doctoral student in biology education and a graduate research assistant for the Institute for P-12 Engineering Research and Learning (INSPIRE) at Purdue University. She received her M.S. in agriculture in Fishery Resources from Huazhong Agricultural University and B.S. in Biological Science from Shaanxi Normal University in China. Her research includes investigating elementary school teachers' evaluations of teacher professional development (TPD) in engineering and identifying students' stereotyped images of engineering and engineers.

\section{Prof. Heidi A. Diefes-Dux, Purdue University, West Lafayette}

Heidi A. Diefes-Dux is a Professor in the School of Engineering Education at Purdue University. She received her B.S. and M.S. in Food Science from Cornell University and her Ph.D. in Food Process Engineering from the Department of Agricultural and Biological Engineering at Purdue University. She is a member of Purdue's Teaching Academy. Since 1999, she has been a faculty member within the FirstYear Engineering Program, teaching and guiding the design of one of the required first-year engineering courses that engages students in open-ended problem solving and design. Her research focuses on the development, implementation, and assessment of model-eliciting activities with authentic engineering contexts. She is currently the Director of Teacher Professional Development for the Institute for P-12 Engineering Research and Learning (INSPIRE) and a member of the educational team for the Network for Computational Nanotechnology (NCN).

\section{Dr. Johannes Strobel, Texas A\&M}

Dr. Johannes Strobel is Director, Educational Outreach Programs and Associate Professor, Engineering and Education at Texas A\&M. After studying philosophy and information science at three universities in Germany, he received his M.Ed. and Ph.D. in Learning Technologies from the University of MissouriColumbia. He worked at Concordia University, Montreal and has been the director of the Institute of P-12 Engineering Research and Learning at Purdue University. NSF and several private foundations fund his research. His research and teaching focuses on engineering as an innovation in P-12 education, policy of P-12 engineering, how to support teachers and students' academic achievements through engineering, the measurement and support of the change of 'engineering habits of mind' particularly empathy and the use of cyber-infrastructure to sensitively and resourcefully provide access to and support learning. 


\title{
Effects of Continuous Teacher Professional Development in Engineering on Elementary Teachers
}

\author{
(Research-to-Practice) \\ Strand: Addressing the NGSS: Supporting K-12 Teachers in Engineering Pedagogy and \\ Engineering-Science Connections
}

\section{Introduction}

As the Next Generation Science Standards (NGSS) embraces engineering as practices interacting with science, technology, and society, engineering becomes one of the key disciplines for K-12 education for future generations ${ }^{1}$. To prepare teachers to teach K-12 engineering, continuous support for teachers through teacher professional development (TPD) is necessary. In the past 20 years, many teachers have experienced TPD in engineering ${ }^{2}$. However, for most teachers, it has been a one-time opportunity because engineering is not a required subject to be taught in class in many states and lack of funding limited continuous support for teachers after their initial engineering TPD $^{2}$.

TPD is designed to change teachers' attitudes, beliefs, and perceptions, so such changes are expected to influence teachers' classroom practices and result in improved student learning ${ }^{3,4}$. However, one-time TPD is not enough to achieve desired teacher change because (a) changing practice requires prolonged engagement with a new practice, (b) it might be hard for teachers to make an immediate change after their TPD attendance, or (c) teachers may not want to continue different teaching approaches for various reasons 5 . Therefore, it is important to track teachers' perceptions and teaching practices after TPD, as well as guide teachers to apply their teaching practices in different ways after their first TPD. Additionally, there is a need to provide continuing support for teachers through follow-on $\mathrm{TPD}^{4,6,7}$ as continuous professional development (CPD) is considered essential for furthering teachers' content knowledge, improving teacher practice, and making teachers successful in their teaching ${ }^{8,9,10}$. Providing prolonged professional development seems to be particularly true for engineering, which is a new content area for most teachers ${ }^{11,26}$.

\section{A. Role of Continuing Professional Development (CPD)}

Continuing professional development (CPD) is defined as "all types of professional learning undertaken by teachers beyond the initial point of training" (p. 6) ${ }^{12}$. CPD for teachers, on the one hand, helps teachers maintain their interest in and enthusiasm for teaching by refreshing and extending their content knowledge ${ }^{7}$. On the other hand, CPD brings about the sustained implementation of research-based practices and provides long-term support for teachers' implementation of new classroom practices for a successful TPD ${ }^{6}$. Since CPD ultimately increases the teachers' potential to benefit students' learning, it is considered to be an important way to fulfill social expectations of the teaching profession and meet students' needs, as well as a vital aspect of being a professional ${ }^{13,14}$.

Given the importance of CPD, there is a call for CPD in the literature. Guskey (2002) ${ }^{4}$ stated that it is critical to provide continued support, encouragement, and subtle pressure to teachers, so that new practices and techniques from the TPD are used habitually. Loucks-Horsley et al. (1987) 
stated that successful TPD must be seen as a process instead of an event, because it is difficult to learn to be proficient at something new or find meaning in a new way of doing things, and it is likely to be slow and require extra work for individuals to increase their competence or for an organization to enhance its effectiveness ${ }^{15}$. Thus, it is imperative to make TPD a continuous and ongoing program ${ }^{16}$. Moreover, the National Staff Development Council (NSDC) Standards has CPD as one of its context standards: staff development, which improves the learning of all students and demands skillful school and district leaders to continuously guide the improvement of their instruction ${ }^{17}$.

\section{B. CPD Evaluations}

CPD needs to be evaluated to justify decisions made by school management and funding agencies, to maximize teachers' benefit about the effects of CPD, and to improve the effectiveness of CPD ${ }^{18}$. Whitehouse $(2011)^{18}$ reported several outcomes of CPD that can be used to measure the effectiveness of CPD. These outcomes include teachers' content and pedagogical knowledge, teachers' self-efficacy, and the use of specific behaviors in their teaching, as well as students' learning outcomes. Many studies have evaluated CPD from different aspects in varied grade and subject areas ${ }^{19,20}$. Some of the studies identified key factors that make CPD implementation successful.

For example, Neimeyer, Taylor, and Cox $(2012)^{20}$ evaluated the contribution of different CPD activities to ongoing professional competence and reported that CPD activities with self-directed learning, peer consultation, and formal continuing education significantly benefit ongoing professional competence. However, CPD activities, such as serving on professional boards, conducting client assessments, and taking graduate courses, provided minimum benefit. Armour and Makopoulou (2012) ${ }^{19}$ evaluated CPD in England and found that positive factors of CPD were chances for interactive learning, cooperate participation, and localized implementation of CPD, which means that the provision of CPD is tailored to meet local needs. Although this reported CPD failed to extend teachers' learning in their interest area, it generated teacher enthusiasm for learning and was evaluated by participants as a successful program.

Some studies evaluated the outcome of CPD by examining teachers' teaching practices and beliefs. For example, Desimone, Porter, Garet, Yoon, and Birman (2002) ${ }^{10}$ examined the effects of a longitudinal TPD on teachers' teaching practices in mathematics and science from 19961999. They found that the provision of active learning opportunities in TPD made teachers' use of new classroom practices increase. Fisher, Lapp, Flood, and Moore (2006) ${ }^{21}$ described a CPD initiative that guided teachers' instruction by linking teaching and assessment. After this CPD, teachers improved their knowledge, skills, and dispositions, and they were able to apply what they learned from the CPD to improve their students' learning. Taitelbaum, Mamlok-Naaman, Carmeli, and Hofstein $(2008)^{22}$ reported that teachers became more reflective and aware of their teaching practices after they participated in a CPD program. de Vries, van de Grift, and Jansen $(2012)^{23}$ explored the link between teachers' beliefs about learning and teaching and their participation in CPD. They found that teachers with student-oriented beliefs wanted to participate more in CPD, while teachers with the subject-matter-oriented beliefs demonstrated no relationship with CPD. 
While the importance of CPD is well documented in the literature and many studies have evaluated the impact of CPD on teachers and students in different subject areas, few studies have investigated the outcomes of CPD in K-12 engineering education. To fully evaluate the outcome of CPD in engineering on teachers, studies with the purpose of examining teachers' thinking, beliefs, perceptions, and teaching practices after they attend CPD need to be done.

\section{Project Background}

As part of a five-year longitudinal project funded by an National Science Foundation (NSF) grant from 2008 to 2012, the Institute for P-12 Engineering Research and Learning (INSPIRE) established at Purdue University offered a one-week introductory engineering TPD program each summer and a three-day follow-on TPD program the following year for grades two to four teachers in a large school district located in south-central United States. During their first oneweek Summer Academy, teachers were exposed to engineering content by engaging in and reflecting on various engineering lessons. These lessons included developing working definitions of technology and engineering, an introduction to an engineering design process (EDP), two Engineering is Elementary (EiE) units ${ }^{24}$, and one mathematical model development activity. Teachers had opportunities to engage with practicing engineers at the K-12 Engineering Education Dinner or Lunch and on an engineering facility tour. Teachers also practiced delivering an engineering lesson with elementary students invited to an engineering day. This first academy is described in detail by Yoon, Kong, Diefes-Dux, and Strobel ${ }^{25}$ and an overall model of teacher adoption and expertise development is described in detail by Sun and Strobel $^{27}$.

In the following school year, teachers were requested to teach introductory lessons titled "What is Technology?" and "What is Engineering?" as well as an introductory engineering design challenge. After teaching introductory lessons, teachers engaged their students in an EiE unit composed of four individual lessons ${ }^{24}$. Each grade adopted a different EiE unit. During the school year, a local liaison was available to assist with any questions, provide in-class support, and support additional afterschool workshops as appropriate.

After their first year of integration of engineering in class, teachers were invited to attend a follow-on three-day Summer Academy. In the second TPD, teachers had time to debrief their implementation of the EiE units and their lessons, discuss concerns and lessons learned, and share with other teachers at the same grade level lesson materials prepared by themselves and student work on engineering activities. The second academy also included activities to bolster teachers' understanding of the field of engineering depicted in their grade level adopted EiE unit. The opportunities for exploring math and science concepts through these activities were also highlighted. Assessment strategies were discussed in association with each of these activities.

In small grade-level groups, teachers used internet resources to assemble content for a poster or handout about their particular EiE field of engineering focusing on the actions of that particular kind of engineer, the resources that engineer uses, and the people that interact with that engineer. Teachers also had a chance to again interact with practicing engineers attending the K-12 Engineering Education Lunch. 


\section{Purpose of the Study}

Since the follow-on TPD is one kind of CPD, we examined changes in teachers' beliefs and attitudes to understand how CPD with engineering impacts elementary teachers differently from their first to their second participation. The research questions were as follows: (a) how did the most important things that teachers learned from the engineering TPD change from their first to second TPD experience?; (b) how did the meaningful aspects of the engineering TPD for teachers change from their first to second experience?; and (c) how did teachers' motivation to attend the engineering TPD change from their first to second experience?

\section{Methods}

\section{A. Participants}

Participants in this study are elementary teachers from a single large school district participating in a NSF funded research program. During the project period, from 2008 to 2012, teachers attended their first Summer Academy in one year and then returned to attend their second Summer Academy in the following year. While teachers from 2008 to 2010 were volunteers who applied in teams of four or more to ensure colleague support for engineering implementation post-academy, teachers who participated in the first Summer Academy in 2011 were required to attend the academy as part of their school's participation in the NSF project. All teachers in all years (2008-2011) taught or were instructional facilitators for grades 2 to 4, except two teachers who taught grade 5 in 2011. Classroom teachers were assigned a classroom of between 14 to 23 students in the following school year.

From 2008 to 2011, 157 elementary teachers received engineering TPD for the first time. Among them, 145 teachers $(92.4 \%)$ responded to a survey at the end of their first Summer Academy TPD program and 97 teachers (61.8\% of 157) returned the following year after teaching engineering in their classrooms. Among the returnees, 92 teachers (94.8\% of 97) answered the same survey at the end of their second Summer Academy. Table 1 shows the number of participants and respondents on the survey according to their year and times of attendance, and Table 2 shows demographic information for the 157 teachers.

Table 1. Number of Participants of TPD in Engineering by Year

\begin{tabular}{|c|c|c|c|c|c|}
\hline \multicolumn{3}{|c|}{ First Summer Academy } & \multicolumn{3}{|c|}{ Second Summer Academy } \\
\hline Year & Participants & Respondents & Year & Participants & Respondents \\
\hline 2008 & 32 & 29 & 2009 & 23 & 23 \\
\hline 2009 & 36 & 36 & 2010 & 24 & 20 \\
\hline 2010 & 30 & 30 & 2011 & 23 & 23 \\
\hline 2011 & 59 & 50 & 2012 & 27 & 26 \\
\hline Total & 157 & 145 & Total & 97 & 92 \\
\hline
\end{tabular}


Table 2. Characteristics of Teachers

\begin{tabular}{llr}
\hline \multirow{4}{*}{ Gender } & \multicolumn{1}{c}{ Category } & \multicolumn{1}{c}{$N$} \\
\cline { 2 - 3 } Ethnicity & Female & 144 \\
& Male & 13 \\
& Asian & 0 \\
& Black & 9 \\
& Hispanic & 24 \\
& White & 115 \\
& Multiracial & 6 \\
& Non-respondent & 3 \\
Grade & 2 & 41 \\
& 3 & 40 \\
& 4 & 60 \\
& 5 & 2 \\
& Facilitator & 14 \\
\hline Total & & 157 \\
\hline
\end{tabular}

\section{B. Instrument}

After each engineering TPD, INSPIRE administered a Summer Academy evaluation survey to teachers with the purpose of evaluating the impact of the engineering TPD program on teachers $^{25}$. The survey consists of ten five-point Likert type questions (rated as very poor, poor, fair, good, and excellent or strongly agree, agree, neutral, disagree, and strongly disagree) and eight open-ended questions. For the purpose of this study, we only examined the open-ended questions from the survey as they pertained to our research questions. Among the eight openended questions, seven questions inquire about three important things teachers learned from the engineering TPD, meaningful aspects of the engineering TPD, how they were motivated by the TPD, teacher's plans for future classroom instruction, suggestions for future topics, and comments regarding the Summer Academy, including one question to clarify responses on the prior questions if needed. The last question requested comments about the instructors. This study utilized elementary teachers' responses on the first three open-ended questions to assess teachers' beliefs and attitudes about the engineering TPD.

\section{Data Analysis}

To investigate the impact of the engineering CPD on teachers, we examined changes in teachers' responses to the survey from their first to second time engineering TPD participation. To do this, we adopted the coding schemes developed by Yoon et al. $(2013)^{25}$ that employed an inductive analysis and creative synthesis strategy ${ }^{28,29}$. In their study, 302 teachers in grades K-8, who participated in the engineering TPD offered by INSPIRE, responded to the same survey and the data were analyzed to examine teachers' satisfaction, beliefs, and attitudes toward their first time engineering TPD. The first survey responses from 157 participants of this study were a part of 
the data coded by Yoon et al. (2013) ${ }^{25}$. Teachers' responses on the survey from the follow-on engineering TPD participation were coded in the same manner based on the same coding schemes and the common themes emerged from the coding schemes. Please refer to the study by Yoon et al. (2013) ${ }^{25}$ for the description of the themes that appeared in the responses to each open-ended question. Descriptive statistics were applied to compare teachers' first to second TPD experience: the frequency with which each theme appeared in teachers' raw responses was calculated.

\section{Results and Discussion}

\section{A. Characteristics of Teacher Responses on the Open-ended Question}

Table 3 shows teachers' response rates varied by the open-ended questions. On average, 92\% ( $n$ $=133)$ and $85 \%(n=79)$ of participants responded to the three open-ended questions in the first and second survey, respectively. The response rates on the questions in the second survey were lower than on the first survey. Similar to the study by Yoon et al. (2013) ${ }^{25}$ about first time engineering experiences, teachers provided a wide range of responses on both the first and second survey, and a number of different themes appeared in each teacher's response. In some cases, teachers did not provide the requested number of responses to the open-ended questions. For example, when asked about the three most important things learned from the engineering TPD, teachers provided one to several things.

Table 3. Response Rates on the Two Open-ended Questions

\begin{tabular}{|c|c|c|c|c|c|c|c|c|}
\hline \multirow{3}{*}{ Main Theme of the Question } & \multicolumn{4}{|c|}{ First TPD $(N=145)$} & \multicolumn{4}{|c|}{ Second TPD $(N=92)$} \\
\hline & \multicolumn{2}{|c|}{$\begin{array}{c}\text { Valid } \\
\text { Responses }\end{array}$} & \multicolumn{2}{|c|}{$\begin{array}{c}\text { Missing } \\
\text { Responses }\end{array}$} & \multicolumn{2}{|c|}{$\begin{array}{c}\text { Valid } \\
\text { Responses }\end{array}$} & \multicolumn{2}{|c|}{$\begin{array}{c}\text { Missing } \\
\text { Responses }\end{array}$} \\
\hline & $n$ & $\%$ & $n$ & $\%$ & $N$ & $\%$ & $n$ & $\%$ \\
\hline Important learning & 138 & 95.2 & 7 & 4.8 & 85 & 92.4 & 7 & 7.6 \\
\hline Meaningful aspects & 128 & 88.3 & 17 & 11.7 & 77 & 83.7 & 15 & 16.3 \\
\hline Motivation & 133 & 91.7 & 12 & 8.3 & 74 & 80.4 & 18 & 19.6 \\
\hline
\end{tabular}

\section{B. Important Things that Teachers Learned from the Engineering TPD}

For the teachers' responses concerning the most important things learned from the engineering TPD, fourteen themes emerged (Table 4). Figure 1 shows the frequency distribution of the fourteen themes following teachers' first and second engineering TPD. After their first engineering TPD, the top three most important things that teachers learned were the engineering design process (EDP) (72.5\%) followed by knowledge about engineering and technology (47.1\%) and new teaching strategies (31.9\%). However, after their second engineering TPD, teachers equally mentioned learning about new teaching strategies and engineering activities (36.5\% each) as the most important, followed by knowledge about engineering and technology $(34.1 \%)$ and the engineering design process (32.9\%). The big drop in the percentage on the EDP indicates that more teachers became familiar with the EDP during their first engineering TPD. The priority on learning about teaching strategies after the second TPD implies that teachers considered practical 
strategies of teaching engineering more important than learning content (e.g., the knowledge about engineering and technology and the EDP) after their first implementation of engineering in their classrooms. The frequency of the theme, "Making mistakes is OK," changed from 9.4 to $0 \%$. This indicates that failure as part of an engineering design is not a new concept for teachers during their second TPD.

Table 4. Themes of the Important Things that Teachers Learned from the Engineering TPD ${ }^{25}$

\begin{tabular}{|c|c|}
\hline Theme & Description \\
\hline $\begin{array}{l}\text { Engineering } \\
\text { Design Process } \\
\text { (EDP) }\end{array}$ & $\begin{array}{l}\text { The EDP that encompasses iterative steps of ask, imagine, plan, create, test, } \\
\text { and improve; and that is distinct from scientific inquiry but incorporates it } \\
\text { as a step. }\end{array}$ \\
\hline $\begin{array}{l}\text { Engineering/ } \\
\text { Technology } \\
\text { Knowledge }\end{array}$ & $\begin{array}{l}\text { Pedagogical content knowledge about engineering and technology, } \\
\text { including the nature of engineering and technology, introduction of } \\
\text { different engineering fields, what engineers do, connections of engineering } \\
\text { to the real world examples, and usage of engineering vocabulary. }\end{array}$ \\
\hline $\begin{array}{l}\text { Engineering } \\
\text { Integration }\end{array}$ & $\begin{array}{l}\text { Effective ways to integrate engineering into current curriculum, such as } \\
\text { language arts, social studies, mathematics, science, and art lessons. }\end{array}$ \\
\hline $\begin{array}{l}\text { Teaching } \\
\text { Strategies }\end{array}$ & $\begin{array}{l}\text { Teaching practices that include different ways to improve problem solving } \\
\text { and critical thinking skills: questioning techniques to elicit student } \\
\text { responses; writing techniques, such as expository, procedural, and reflective } \\
\text { journal writing; and how to make learning more hands-on, etc. }\end{array}$ \\
\hline Student Teamwork & $\begin{array}{l}\text { Team building that fosters positive peer interaction and cooperative } \\
\text { learning among students to solve problems and complete projects together. }\end{array}$ \\
\hline $\begin{array}{l}\text { Engineering } \\
\text { Activities }\end{array}$ & $\begin{array}{l}\text { Engineering activities in general, which are hands-on and practical to use in } \\
\text { the classroom. }\end{array}$ \\
\hline $\begin{array}{l}\text { Model-Eliciting } \\
\text { Activities (MEAs) }\end{array}$ & Use of MEA lessons to bring real world mathematics into the classroom. \\
\hline $\begin{array}{l}\text { Engineering is } \\
\text { Elementary }(E i E)\end{array}$ & Instructional modeling of EiE lessons. \\
\hline $\begin{array}{l}\text { Student } \\
\text { Motivation }\end{array}$ & $\begin{array}{l}\text { Teaching engineering in interesting and meaningful ways to increase } \\
\text { students' interest in engineering and to encourage students to develop } \\
\text { confidence in learning engineering and consider future careers as engineers. }\end{array}$ \\
\hline $\begin{array}{l}\text { Making Mistakes } \\
\text { is O.K. }\end{array}$ & $\begin{array}{l}\text { It is O.K. to fail at an engineering task because students can learn from their } \\
\text { mistakes. }\end{array}$ \\
\hline $\begin{array}{l}\text { Teacher } \\
\text { Motivation }\end{array}$ & $\begin{array}{l}\text { An increase of teachers' interest and confidence in learning and teaching } \\
\text { engineering. }\end{array}$ \\
\hline $\begin{array}{l}\text { Anyone can do } \\
\text { Engineering }\end{array}$ & Anyone can do and all ages can learn engineering. \\
\hline Engineering is Fun & Engineering is fun for teachers and can be fun for their students \\
\hline $\begin{array}{l}\text { Teacher } \\
\text { Teamwork }\end{array}$ & $\begin{array}{l}\text { Collaboration among teachers from the same grade or different grade levels } \\
\text { to incorporate engineering into their classrooms. }\end{array}$ \\
\hline
\end{tabular}




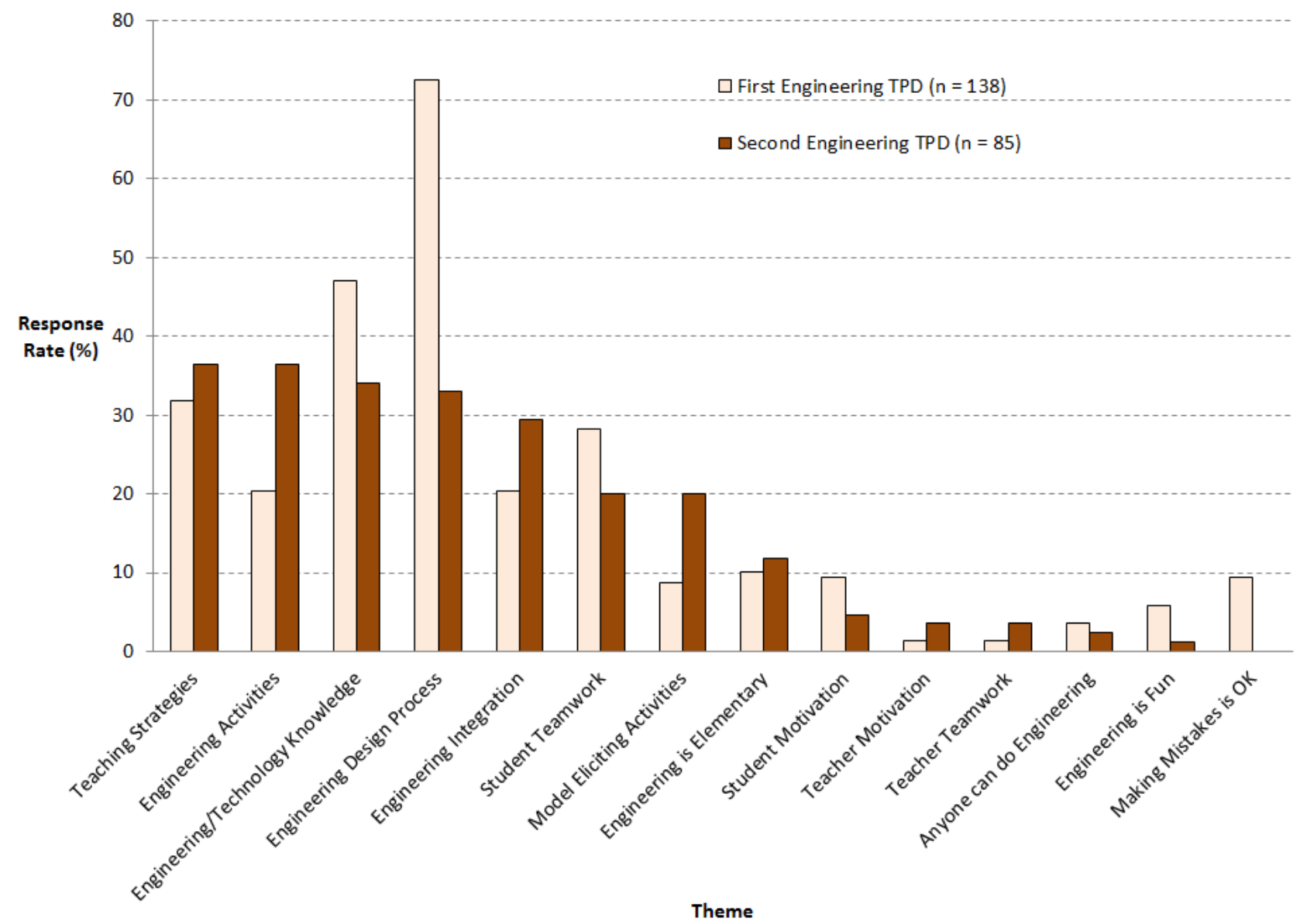

Figure 1. Most important things that teachers learned from the engineering TPD

\section{Meaningful Aspects of the Engineering TPD for Teachers}

While thirteen themes (Table 5) emerged from the teachers' responses on the meaningful aspects of the engineering TPD after their first engineering TPD, only eleven themes appeared in the teachers' responses after second engineering TPD (Figure 2). The two activities that were dropped (i.e. practicing with real students and field trip) were not included in the second engineering TPD. Similar to the first engineering TPD, teachers indicated that hands-on approaches were the most meaningful (50.8\% in the first and $29.9 \%$ in the second survey) followed by application to classroom (28.1\% in the first and $28.6 \%$ in the second survey). Interestingly, more teachers $(26.6 \%)$ perceived that interaction with peers was meaningful in the second than the first engineering TPD (14.8\%). During the CPD, teachers were able to interact with same and/or different grade-level teachers and discuss teaching strategies with teachers who had implemented their engineering lessons in different ways. This implies that after their implementation of engineering in class, more teachers valued collaboration with peers and working as a team to improve their engineering knowledge and teaching practice through CPD.

While after the first engineering TPD, teachers barely mentioned $E i E(0.8 \%)$ and ModelEliciting Activities (MEAs) (1.6\%) were meaningful aspects of engineering TPD, more teachers 
mentioned that EiE (9.1\%) and MEAs (5.2\%) were meaningful after the second engineering TPD. As these activities are more learning and coordination intensive than the introductory engineering activities, teachers may have been overwhelmed by them during their first TPD. With a year of teaching experience behind the teachers, they may have been more ready to find meaning in these activities.

Table 5. Themes of the Meaningful Aspects of the Engineering TPD ${ }^{25}$

\begin{tabular}{|c|c|}
\hline Theme & Description \\
\hline $\begin{array}{l}\text { Hands-on } \\
\text { Approaches }\end{array}$ & $\begin{array}{l}\text { Hands-on approaches help teachers learn engineering concepts better with } \\
\text { more fun in the learning process. }\end{array}$ \\
\hline TPD Instruction & $\begin{array}{l}\text { Instructions/presentations were clear, helpful, and well balanced with } \\
\text { activities, including sufficient practice, application, and reflection time. } \\
\text { Instructors were friendly, knowledgeable, and encouraging. }\end{array}$ \\
\hline $\begin{array}{l}\text { Application to } \\
\text { Classroom }\end{array}$ & $\begin{array}{l}\text { What teachers learned from the engineering TPD can be easily applied to } \\
\text { classroom instruction. Teachers can integrate engineering in their subject } \\
\text { areas, such as mathematics and science, and adopt the materials and lesson } \\
\text { plans from the Summer Academy to their curriculum. }\end{array}$ \\
\hline $\begin{array}{l}\text { Learning New } \\
\text { Knowledge }\end{array}$ & $\begin{array}{l}\text { Teachers valued learning new knowledge and ideas. They gained } \\
\text { knowledge about what engineers do, what engineering/technology is, and } \\
\text { how engineering/technology is related to real life. }\end{array}$ \\
\hline $\begin{array}{l}\text { Interaction with } \\
\text { Peers }\end{array}$ & $\begin{array}{l}\text { Teachers collaborated with peers and worked as a team. They were able to } \\
\text { interact with the same and/or different grade-level teachers and discuss } \\
\text { with other teachers who had implemented engineering. }\end{array}$ \\
\hline $\begin{array}{l}\text { Engineering Design } \\
\text { Process (EDP) }\end{array}$ & Teachers had a lot of opportunities to go through the EDP. \\
\hline $\begin{array}{l}\text { Practicing with } \\
\text { Real Students }\end{array}$ & $\begin{array}{l}\text { Teachers had an opportunity to teach engineering lessons designed by } \\
\text { themselves to a small group of real students. }\end{array}$ \\
\hline Teacher Motivation & $\begin{array}{l}\text { Teachers were engaged in learning engineering and developed confidence } \\
\text { in teaching engineering. }\end{array}$ \\
\hline Being a Student & $\begin{array}{l}\text { Teachers took the role as learners like students during the engineering } \\
\text { TPD. }\end{array}$ \\
\hline $\begin{array}{l}\text { Meeting with Real } \\
\text { Engineers }\end{array}$ & Teachers had a chance to interact with and learn from actual engineers. \\
\hline Field Trip & $\begin{array}{l}\text { Teachers had a field trip to university facilities or manufacturing plants, } \\
\text { such as Driscoll, Doskocil, wetlands, and wind farms which brought real } \\
\text { life aspects of engineering to teachers. }\end{array}$ \\
\hline $\begin{array}{l}\text { Model-Eliciting } \\
\text { Activities (MEAs) }\end{array}$ & MEAs were useful as a new tool in teaching engineering. \\
\hline $\begin{array}{l}\text { Engineering is } \\
\text { Elementary }(E i E)\end{array}$ & $E i E$ can be adapted to teaching across curriculum. \\
\hline
\end{tabular}




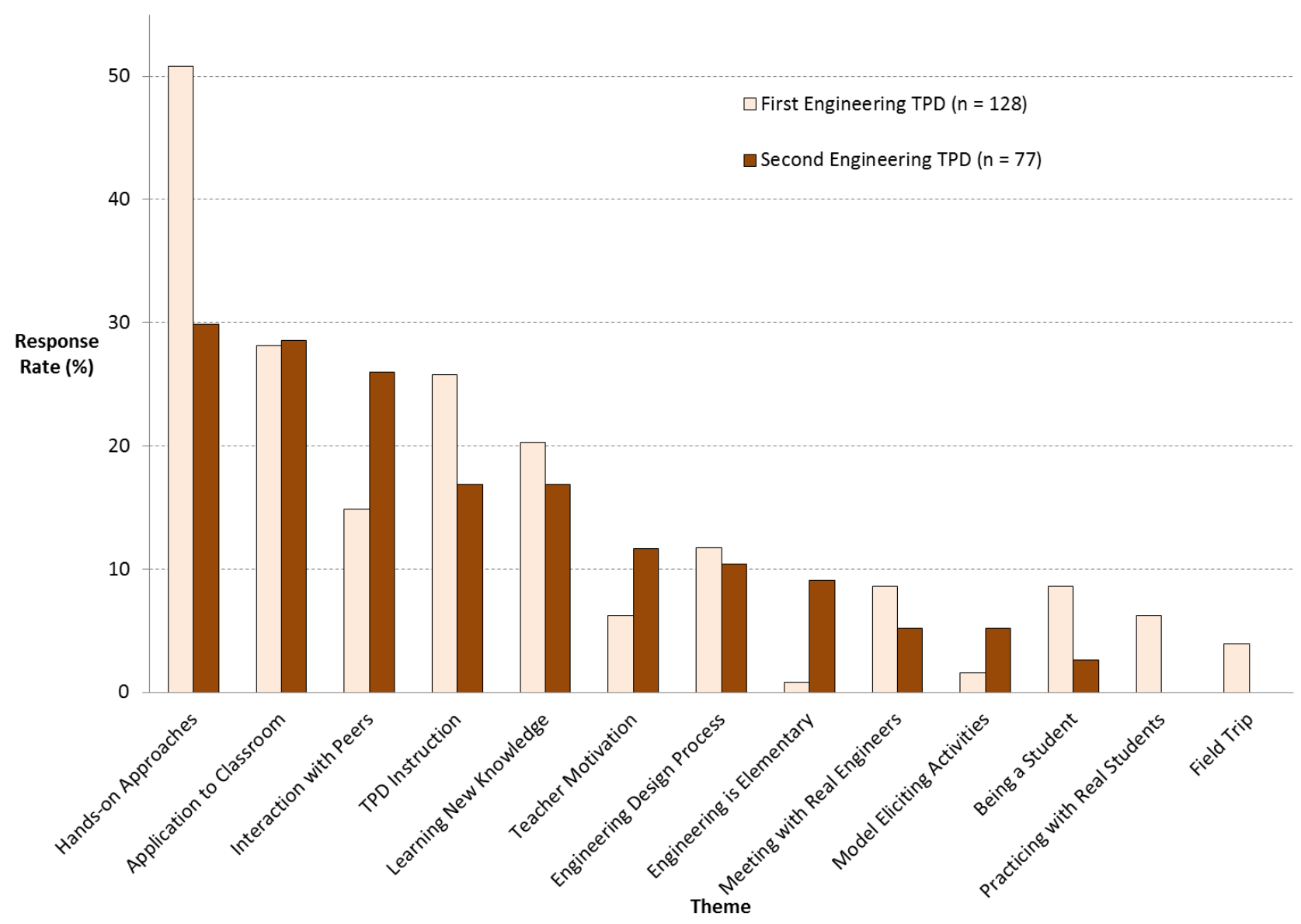

Figure 2. Meaningful aspects of the engineering TPD

\section{Teacher Motivation}

Corresponding to the teachers' responses on the motivating aspects of the Summer Academy, we identified the types of teacher motivation based on Ryan and Deci's (2000) definitions of intrinsic and extrinsic motivations. Table 6 shows description of the types of teacher motivation identified in teachers' responses. In the first TPD, more than half of the teachers (56.4\%) demonstrated intrinsic motivation and a bit lower percentage of the teachers $(51.9 \%)$ showed extrinsic motivation (Figure 3 ). Among those teachers, $21.8 \%$ were both intrinsically and extrinsically motivated to participate in the engineering TPD. About $13 \%$ of teachers revealed that they were not motivated. Some of the reasons addressed in the responses were the length of the academy days $(8 \mathrm{am}-5 \mathrm{pm})$ and the intensity and lack of flexibility in the program. Teachers' motivation during the second TPD was somewhat different from the first TPD; the majority of teachers (70.3\%) felt that they were extrinsically motivated and about half of the teachers (48.6\%) were intrinsically motivated. Among those teachers, $25.7 \%$ were both intrinsically and extrinsically motivated. Few teachers $(2.7 \%)$ reported that they were not motivated. 
Table 6. Types of Teacher Motivation ${ }^{25}$

\begin{tabular}{ll}
\hline Type & Description \\
\hline $\begin{array}{l}\text { Intrinsic } \\
\text { motivation }\end{array}$ & $\begin{array}{l}\text { Teachers are interested in engineering and have the desire to learn new } \\
\text { knowledge through various forms of engineering learning processes, including } \\
\text { engineering activities, the EiE units, MEAs, EDP, and a field trip. }\end{array}$ \\
$\begin{array}{l}\text { Extrinsic } \\
\text { motivation }\end{array}$ & $\begin{array}{l}\text { Teachers are motivated by their oriented goals and/or external controls to learn } \\
\text { from the engineering TPD. For example, teachers were encouraged to learn by } \\
\text { peers or instructors; teachers wanted to learn to integrate engineering into their } \\
\text { classroom because it will be beneficial for their students' learning. }\end{array}$ \\
\hline
\end{tabular}

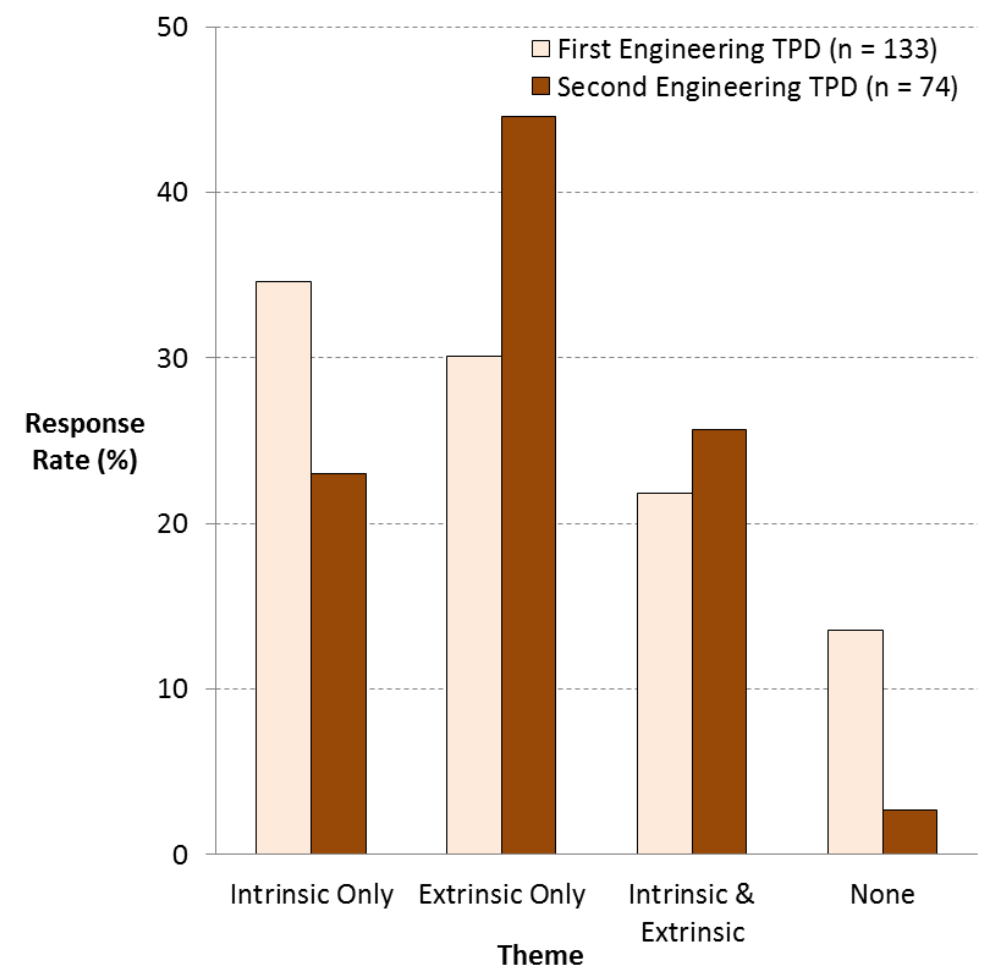

Figure 3. Types of teacher motivation during engineering TPD participation

\section{Conclusion}

The results reveal apparent shifts in teachers' perceptions of engineering TPD between their first and second engineering TPD. While teachers perceived the most important learning from their first TPD related to new content knowledge, they considered practical aspects of teaching engineering and integrating engineering into their curriculum as more important after their second TPD. In addition, teachers valued peer interactions as a meaningful aspect of engineering TPD more in their second TPD than in their first TPD. Even though teachers in the second TPD were more extrinsically motivated, through the evaluation of CPD in this study, we could observe themes with weights different from the first TPD, indicating teachers' changes of beliefs 
and attitudes in positive ways as an effect of the CPD. This suggests the important role of CPD for teachers learning engineering through continuous follow-up and feedback.

Even though the literature provides research evidence about the importance of CPD in different subject areas, there has been little research concerning engineering CPD through empirical studies. This study has provided research evidence about the effects of engineering CPD. As the importance of CPD is evident in K-12 engineering education, we suggest consideration of CPD as a component when planning engineering TPD. While these teachers' engineering experience

was limited to the program offered by INSPIRE, the results revealed the positive impacts of the engineering CPD on teachers from the teachers' point of view.

\section{Acknowledgement}

This work was made possible by a grant from the National Science Foundation (DLR 0822261). Any opinions, findings, and conclusions or recommendations expressed in this material are those of the authors and do not necessarily reflect the views of the National Science Foundation.

\section{Bibliography}

1. NGSS Lead States (2013). Next Generation Science Standards: For States, by States. Washington, DC: The National Academies Press.

2. Katehi, L., Pearson, G., \& Feder, M. A. (2009). Engineering in K-12 education: Understanding the status and improving the prospects. Washington, DC: National Academies Press.

3. Guskey, T. R. (1986). Staff development and the process of teacher change. Educational Researcher, 15, 5-12.

4. Guskey, T. R. (2002). Professional development and teacher change. Teachers and Teaching: theory and practice, $8,381-391$.

5. Loucks-Horsley, S., Harding, C. K., Arbuckle, M. A., Murray, L. B., Dubea, C., \& Williams, M. K. (1987). Continuing to learn: A guidebook for teacher development. Andover, MA: Regional Laboratory for Educational Improvement of the Northeast \& Islands.

6. Klingner, J. K. (2004). The science of professional development. Journal of Learning Disabilities, 37, 248-255.

7. Lewis, J., \& Day, G. (2004). Continuing professional development for teachers. Journal of Biological Education, 38, 144-144.

8. Bredeson, P.V. (2000). Teacher learning as work and at work: exploring the content and contexts of teacher professional development. Journal of In-Service Education, 26, 63-72.

9. Darling-Hammond, L. (1996). The quiet revolution: Rethinking teacher development. Educational Leadership, 53, 4-11.

10. Desimone, L. M., Porter, A. C., Garet, M. S., Yoon, K. S., \& Birman, B. F. (2002). Effects of professional development on teachers' instruction: Results from a three-year longitudinal study. Educational evaluation and policy analysis, 24, 81-112.

11. Liu, W., Carr, R., \& Strobel, J. (2009). Extending teacher professional development through an online learning community: A case study. Journal of Educational Technology Development and Exchange, 2 (1), 99-112.

12. Craft, A. (1996). Continuing professional development. A practical guide for teachers and schools. London: Routledge.

13. Lee, I (2011). Teachers as presenters at continuing professional development seminars in the English-as-aforeign-language context: 'I find it more convincing.' Australian Journal of Teacher Education, 36, 29-42.

14. Pissanos, B. W., \& Allison, P. C. (1996). Continued professional learning: a topical life history. Journal of Teaching in Physical Education, 16, 2-19. 
15. Huberman, M., \& Miles, M. B. (1984). Innovation up close: How school improvement works. New York: Plenum.

16. McLaughlin, M. W., \& Marsh, D. D. (1978). Staff development and school change. Teachers College Record, 80, 70-94.

17. National Staff Development Council. (2001). Standards for staff development. Retrieved from http://www.nsdc.org/standards/index.cfm

18. Whitehouse, C. (2011). Effective continuing professional development for teachers. Retrieved from https://cerp.aqa.org.uk/sites/default/files/pdf_upload/CERP-RP-CW-19052011.pdf

19. Armour, K. M., \& Makopoulou, K. (2012). Great expectations: Teacher learning in a national professional development programme. Teaching and Teacher education, 28, 336-346.

20. Neimeyer, G. J., Taylor, J. M., \& Cox, D. R. (2012). On hope and possibility: Does continuing professional development contribute to ongoing professional competence? Professional Psychology: Research and Practice, 43, 476-486.

21. Fisher, D., Lapp, D., Flood, J., \& Moore, K. (2006). Linking literacy teaching with assessment: a continuing professional development initiative for secondary schools. Literacy, 40, 115-122.

22. Taitelbaum, D., Mamlok-Naaman, R., Carmeli, M., \& Hofstein, A. (2008). Evidence for teachers' change while participating in a continuous professional development programme and implementing the inquiry approach in the chemistry laboratory. International Journal of Science Education, 30, 593-617.

23. de Vries, S., van de Grift, W. J., \& Jansen, E. P. (2013). Teachers' beliefs and continuing professional development. Journal of Educational Administration, 51, 213-231.

24. Cunningham, C. M. (2004). Engineering is Elementary, Boston Museum of Science. Retrieved from http://www.mos.org/eie

25. Yoon, S. Y., Kong, Y., Diefes-Dux, H. A, \& Strobel, J. (2013). K-8 teachers' responses to their first professional development experience in engineering. Proceedings of the 2013 American Society for Engineering Education Annual Conference and Exposition, Atlanta, GA, June 23-26, Washington, DC: ASEE.

26. Strobel, J., \& Sun, Y. (in press 2014). From knowing-about to knowing-to: Development of engineering PCK by elementary teachers through perceived learning and implementing difficulties. American Journal of Engineering Education.

27. Sun, Y. \& Strobel, J. (2013). Elementary engineering education adoption and expertise development model: A mixed inductive/deductive research. Journal of Pre-College Engineering Education Research (J-PEER), 3(1), 32-52.

28. Patton, M. Q. (2002). Qualitative evaluation and research methods (3rd ed.). Newbury Park, CA: Sage.

29. Thomas, D. R. (2006). A general inductive approach for analyzing qualitative evaluation data. American Journal of Evaluation, 27, 237-246. 